\title{
Qualitative and Quantitative Evaluation of the Wastewater Treatment Plant -Type stabilization ponds- of Errachidia City -Morocco- During the Period 2006-2010
}

\author{
${ }^{1,}$ Chaouki HAMID , ${ }^{2,}$ Lahcen ELWATIK \\ ${ }^{1,2,}$ Team of the natural substances, Synthesis and molecular dynamics, Faculty of Science and techniques, \\ Moulay Ismaïl university BP 509, 509, Boutalamine, Errachidia, Morocco Tél (+212) 535574497
}

\begin{abstract}
The present study aims to evaluate the the Wastewater treatment plant in the Errachidia city to know the treatment efficiency for the changing demographics of the city. For this we performed a set of excesses such as: temperature, $\mathrm{pH}$ and conductivity (On-the-spot parameters), the biochemical oxygen demand $\mathrm{BOD}_{5}$, the chemical oxygen demands COD and suspended solids SS (Physico-chemical parameters). The highest yields recorded are observed in the warm periods of the year. These yields are measured from the $\mathrm{BOD}_{5}$ and COD values give respectively $60 \%$ and $51 \%$.
\end{abstract}

KEY WORDS: Water-treatment plant, treatment, On-the-spot parameters, $S S, C O D, B O D_{5}$.

\section{INTRODUCTION}

The demographic, economic and urban increases are the origin of various sources (springs) of environmental pollution, especially in development countries less worried and less made sensitive by the sanitary risks. Among these sources, the production of wastewater which are often released into the receiving water without treatment. This pollution creates many waterborne diseases that can cause some outbreaks. Several methods have been tested for wastewater treatment in order to define the most appropriate and the most efficient treatment techniques [1]. Taking into account the climatic and economic constraints, the lagoon system can be considered suitable for the wastewater treatment especially for small and medium municipalities [2]. Indeed, the stabilization ponds is an extensive process of wastewater treatment which requires no external energy, and produces a lower amount of stabilized sludge with other processes such as aerated lagoons and activated sludge [2-3]. The systems of treatment by stabilization ponds contain several ponds, the most commonly used are anaerobic lagoons, facultative lagoons and maturation lagoons. The Errachidia city has recently seen a demographic development, it is for it that the city saw works of rehabilitation of the former network as well as its extension, allowing the increase of connection to the network, and thus the elevation of the wastewater flow. This led to the necessity of conducting a wastewater treatment plant. Indeed in 2006, the city had a sewage treatment plant type stabilization ponds. To evaluate the performance of the wastewater treatment plant in the Errachidia city, we conducted sampling, measurement and recording of a set of parameters and those over a period from 2006 to 2009.

\section{WASTEWATER TREATMENT PLANT OF ERRACHIDIA}

Errachidia city is located in the south east of Morocco, $320 \mathrm{~km}$ south of Meknes, it has about 86443 inhabitants in 2010, characterized by a dry climate.

Presentation of the station :

\begin{tabular}{|l|l|}
\hline$\bullet$ Date of service & $28 / 02 / 2006$ \\
\hline$\bullet \quad$ Location relative to city center & $3 \mathrm{Km}$ \\
\hline$\bullet \quad$ Location relative to nearest homes & $1 \mathrm{Km}$ \\
\hline$\bullet \quad$ Total land $\left(\mathrm{m}^{2}\right)$ & 540000 \\
\hline$\bullet \quad$ Usable area $\left(\mathrm{m}^{2}\right)$ & 12860 \\
\hline$\bullet \quad$ Type of wastewater treatment plant (WWTP) & stabilization ponds \\
\hline
\end{tabular}

Capacity / Objectives: 


\begin{tabular}{|c|c|}
\hline - Saturation horizon & 2010 \\
\hline - Rated capacity in population equivalent (P-E) & 163000 \\
\hline - $\quad$ nominal flow $\left(\mathrm{m}^{3} / \mathrm{d}\right)$ & 6000 \\
\hline - $\quad$ hourly Peak flow $\left(\mathrm{m}^{3} / \mathrm{d}\right)$ & 7158 \\
\hline - $\quad$ Processing capacity $\left(\mathrm{kg} \mathrm{DBO}_{5} / \mathrm{d}\right)$ & 2943 \\
\hline - Location of treated effluent discharges places & OUED ZIZ \\
\hline - Nature of the receiving environment & Oued saisonnier \\
\hline
\end{tabular}

\section{BUILDINGS DESCRIPTION :}

The treatment plant, it is stabilization ponds type.

it contains :

- Channel Parchal ;

- A manual bar screen bar inclined ;

- Portable flowmeter sigma 950;

- Distribution chamber ;

- Four anaerobic ponds with a surface of peak $2578,16 \mathrm{~m}^{2}$ and $4,5 \mathrm{~m}$ deep -for each-, with a maximum water volume by $7711 \mathrm{~m}^{3}$ lagoon (the sealing of ponds is provided by a layer of clay loam $40 \mathrm{~cm}$ thick) ;

- 2 beds of drying an area of $1250 \mathrm{~m}^{2}$ and $0,45 \mathrm{~m}$ deep for each ;

- A building release of treated water to the Oued Ziz.

\section{Method of sampling}

\section{MATERIALS AND METHODS USED}

Collection of samples are at the entrance of the station (raw water), to the output of each of the four anaerobic ponds and the output of the station. For the sampling frequency three times per week for on-site parameters and quarterly for the physicochemical parameters. Flow measurements are taken at the entrance of the station by a flow meter installed at the entrance of the station.

\section{Measures and methods used}

The measurements are:

- Parameters on site including temperature, conductivity and $\mathrm{pH}$;

- The physico-chemical parameters $\left(\mathrm{BOD}_{5}, \mathrm{COD}, \mathrm{SS}\right)$;

Measurements of $\mathrm{pH}$, conductivity and $\mathrm{BOD}_{5}$ are made respectively by a $\mathrm{pH}$ meter, a conductivity meter and a pulse oximeter. For measurement of COD and SS are respectively performed by the colorimetric method [4] and the gravimetric method [5].

\section{RESULTS AND DISCUSSION}

All measures of thinking monitoring the treatment plant, we collected a set of results which we managed to summarize as follows:

1. The inflow to the wastewater treatment plant of 2006 to 2010 . These results are shown in graphic 1 ;

2. The temperature, conductivity, the $\mathrm{pH}$ of the wastewater at the entrance to the station (raw water) and the outlet (treated wastewater) and the air temperature. We have chosen to present the changes in conductivity, $\mathrm{pH}$ as a function of temperature in the months January and July of 2008, 2009 and 2010 (Graphics 2, 3, 4, 5, 6 and 7)

3. $\mathrm{BOD}_{5}, \mathrm{COD}$ and SS wastewater at the station entrance and exit basins for the years 2008,2009 and 2010 (Tables 1,2 and 3) 
Graphic 1: Variation in average flow the years 2006 to 2010

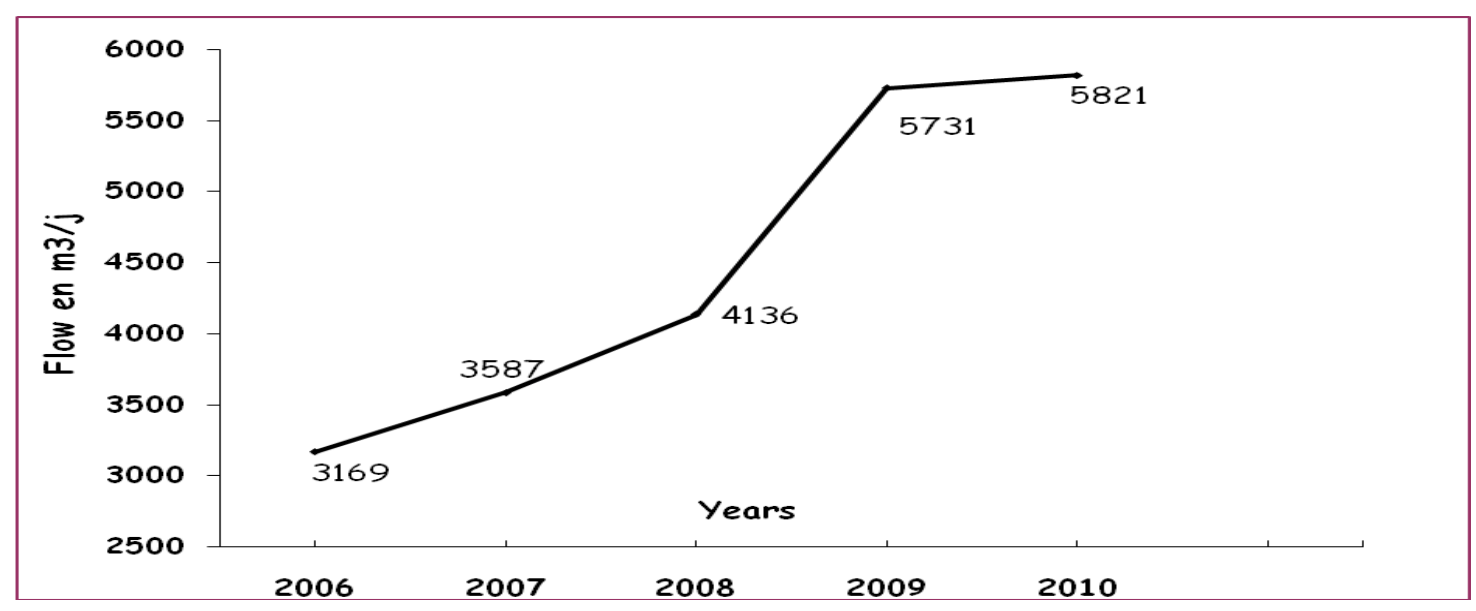

It can be seen that the daily wastewater flow entering the station has increased exponentially from 2006 to 2010 to slow thereafter. This can be explained by the demographic growth of the city and therefore the rate of connection to the sewerage system during this period.

\section{$>$ The conductivity and $p H$}

Electrical conductivity is the ability of a solution to pass an electrical current. This is an indicator of the ion concentration of the electrolyte dissolved in water. It does not identify the specific ions in the water. However, significant increases in conductivity, may be an indicator that pollutant discharges are entered in water. Knowledge of electrical conductivity, tells us a good approximation of the salinity of water. High electrical conductivity often indicates a high salinity, they may be natural or caused by salt polluting discharges [6] Excessive salinity may have adverse effects on wildlife and aquatic flora, dissolved salts exert osmotic pressure on the organisms that live there. Following a sharp increase in salinity, there is a migration and sometimes death of aquatic organisms. Beyond $3000 \mu \mathrm{S} / \mathrm{cm}$, the conditions are unfavorable for normal ecological balance [7] if the conductivity is an important parameter in controlling the quality of drinking water and pollutant discharges, control in the case of irrigation water is of major importance both for natural waters for wastewater. A high salinity of irrigation water leads to undesirable effects on both the physical properties of soil on plant growth and crop yields. The $\mathrm{pH}$ value is also fundamental for the growth of microorganisms that require generally a $\mathrm{pH}$ optimum between 6,5 and 7,5. PH lower than 5 or higher than 8,5 directly affect the growth of micro-organisms

Graphic 2: Variation in the conductivity and $\mathrm{pH}$ of the raw water and treated according to the air temperature during the month 01/2008

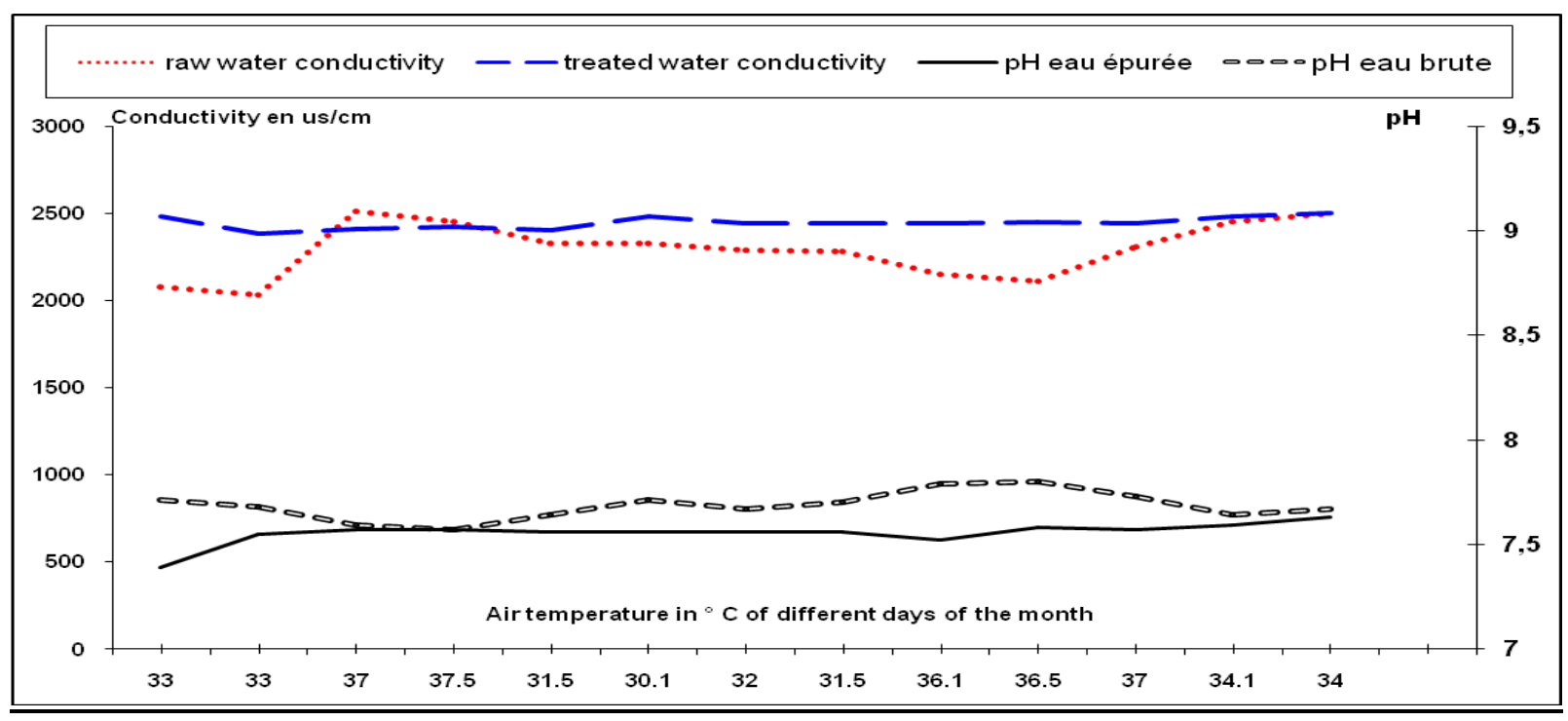


The conductivity during the month of January 2008, varies for raw water between 1734 and $3320 \mu \mathrm{S} / \mathrm{cm}$, and treated water between 2680 and $3110 \mu \mathrm{S} / \mathrm{cm}$. 7,33 .

For $\mathrm{pH}$, it varies between 6,89 to 7,85 for raw water, while for the treated water between the values 7,02 and

Graphic 3: Variation in the conductivity and $\mathrm{pH}$ of the raw water and treated according to the air temperature during the month $07 / 2008$

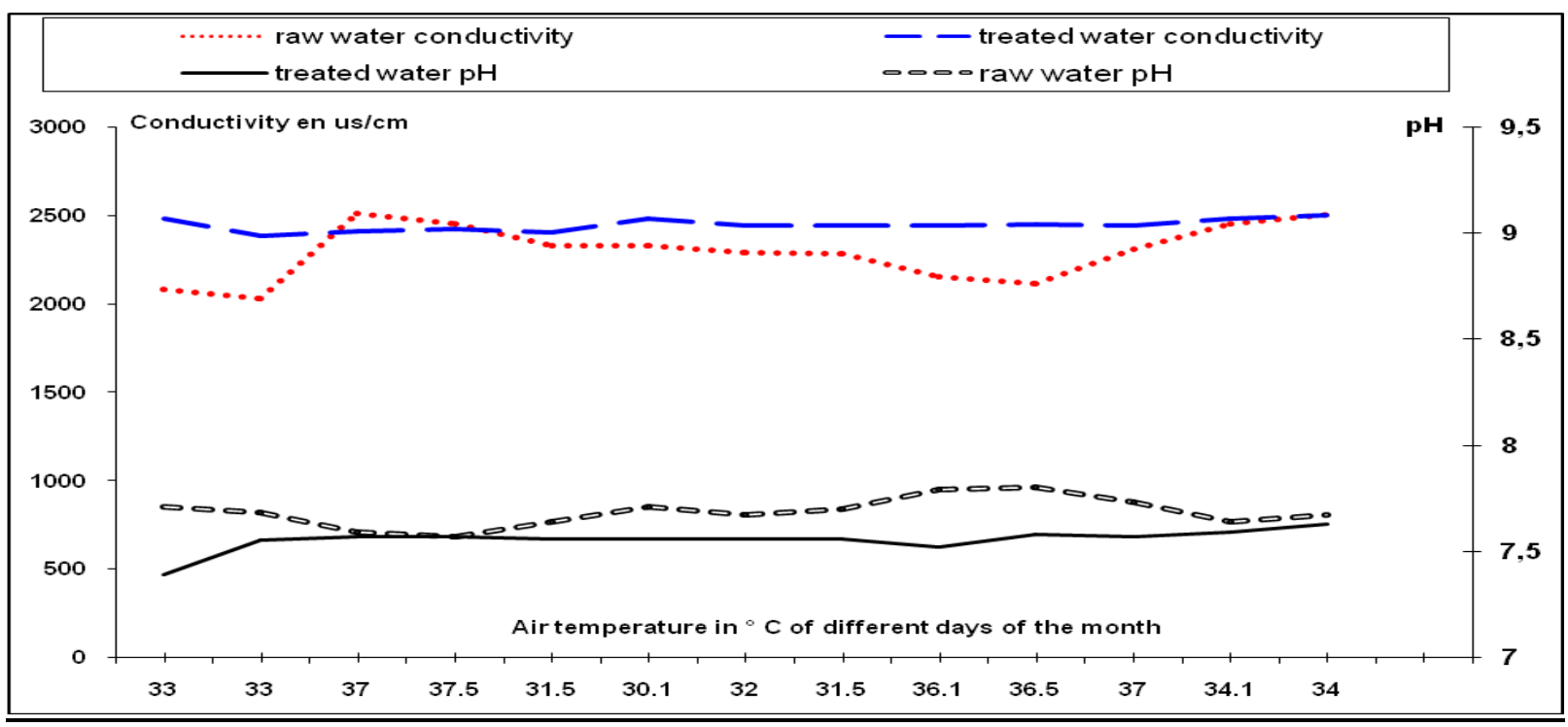

The values of the conductivity of the raw water, for the present month July 2008 up to $2500 \mu \mathrm{S} / \mathrm{cm}$ and a minimum of $2030 \mathrm{~S} / \mathrm{cm}$, to the treated water has maximum conductivity of $2500 \mu \mathrm{S} / \mathrm{cm}$ and minimum $2380 \mu \mathrm{S} / \mathrm{cm}$. $\mathrm{pH}$ values on the one hand to fail over between 7,57 and 7,80 raw water and other treated water for between 7,39 and 7,63.

Graphic 4: Variation in the conductivity and $\mathrm{pH}$ of the raw water and treated according to the air temperature during the month 01/2009

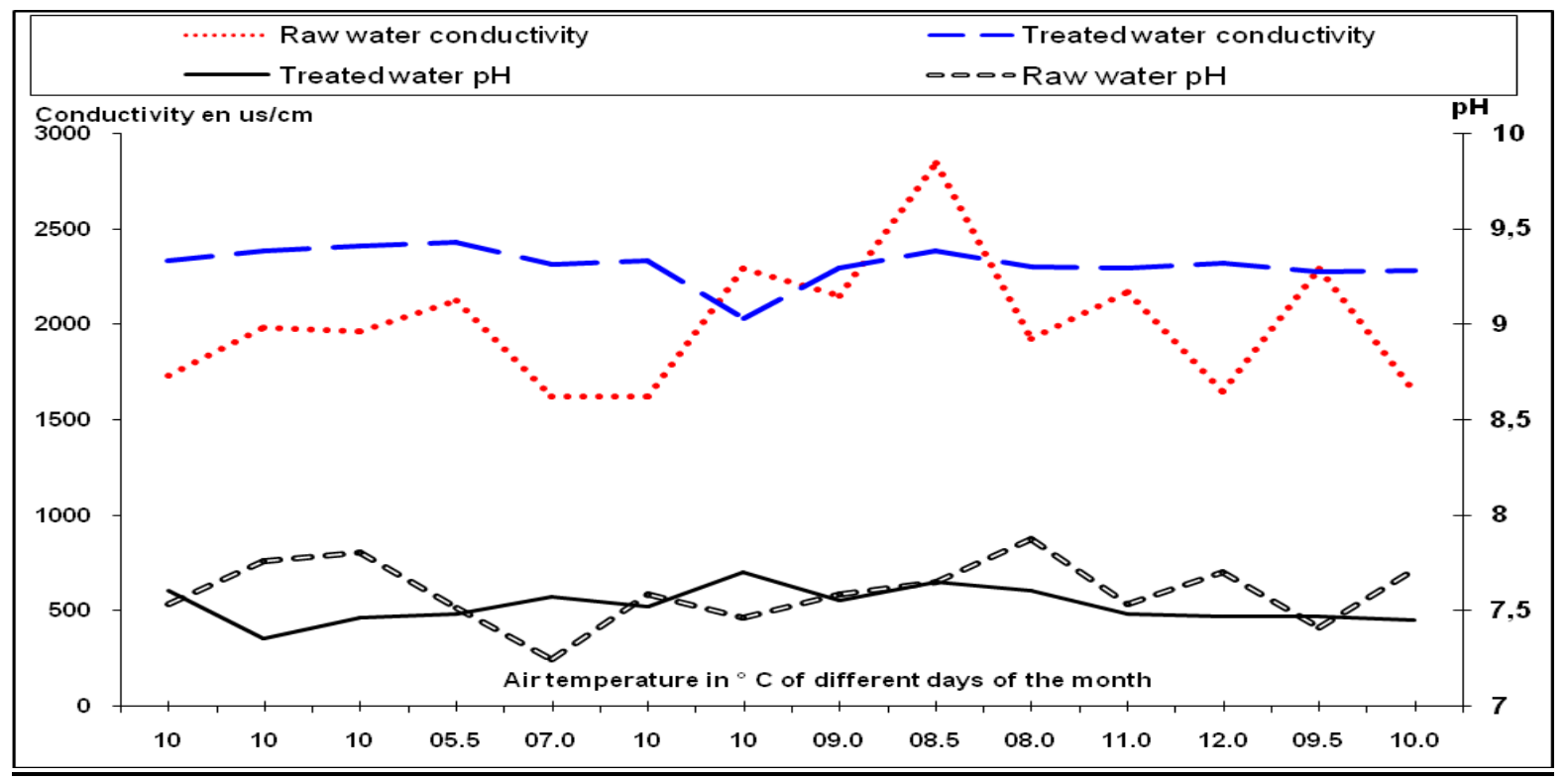

During the month of January 2009, the conductivity changes are included in the range of 1620 and $2290 \mu \mathrm{S} / \mathrm{cm}$ for raw water, and 2030 and $2430 \mu \mathrm{S} / \mathrm{cm}$ for treated water. pH values also vary for raw and treated waters between 7,24 and 7,87 respectively and between 7,35 and 7,70. 
Graphic 5: Variation in the conductivity and $\mathrm{pH}$ of the raw water and treated according to the air temperature during the month 07/2009

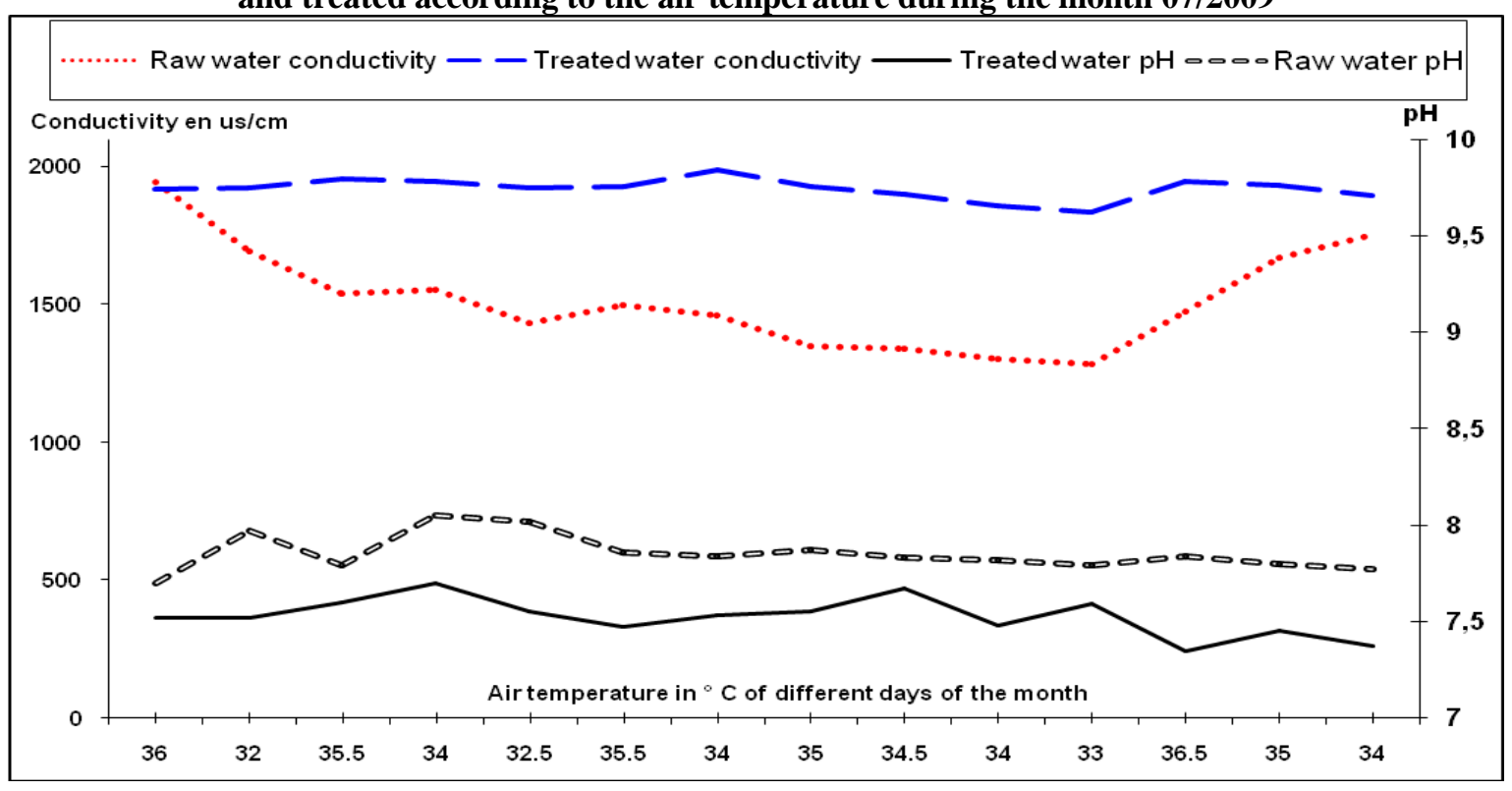

From the figure above, the values of conductivity during the month of July 2009 vary between 1285 and $1943 \mu \mathrm{S} / \mathrm{cm}$ for raw water, and between 1836 and $1957 \mu \mathrm{S} / \mathrm{cm}$ for treated water.

For $\mathrm{pH}$, it varies between 7,70 and 8,05 for raw water and between 7,35 and 7,70 for those treated.

Graphic 6: Variation in the conductivity and $\mathrm{pH}$ of the raw water and treated according to the air temperature during the month $01 / 2010$

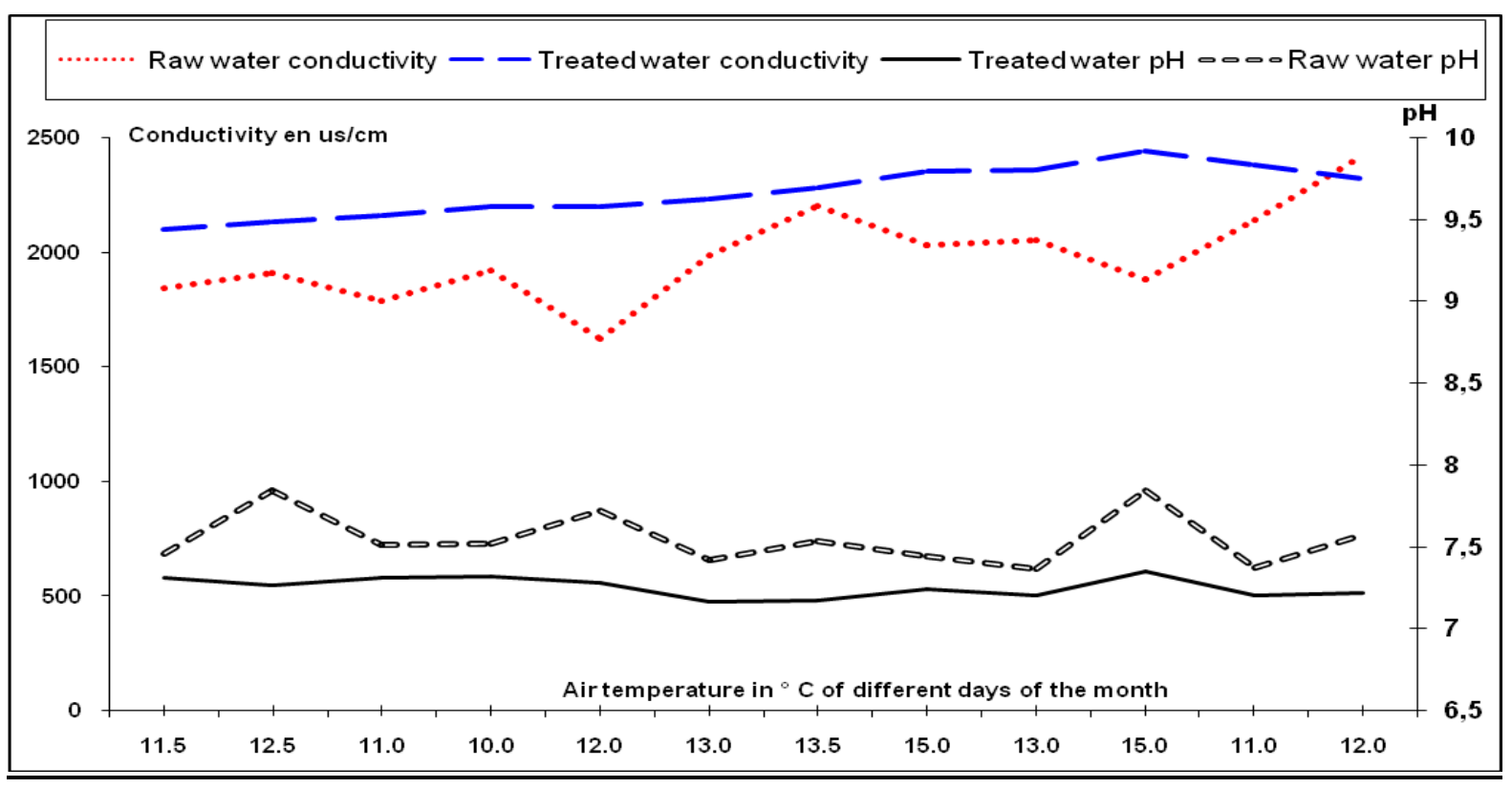

Changes in conductivity and $\mathrm{pH}$ for this month respectively to vary for raw water between 1623 and 2420 $\mu \mathrm{S} / \mathrm{cm}$ and between 7,37 and 7,84 .

For treated wastewater these values vary between 2100 and $2440 \mu \mathrm{S} / \mathrm{cm}$, and between 7,17 and 7,35. 
Graphic 7: Variation in the conductivity and $\mathrm{pH}$ of the raw water and treated in accordance with the air temperature during the month 07/2010

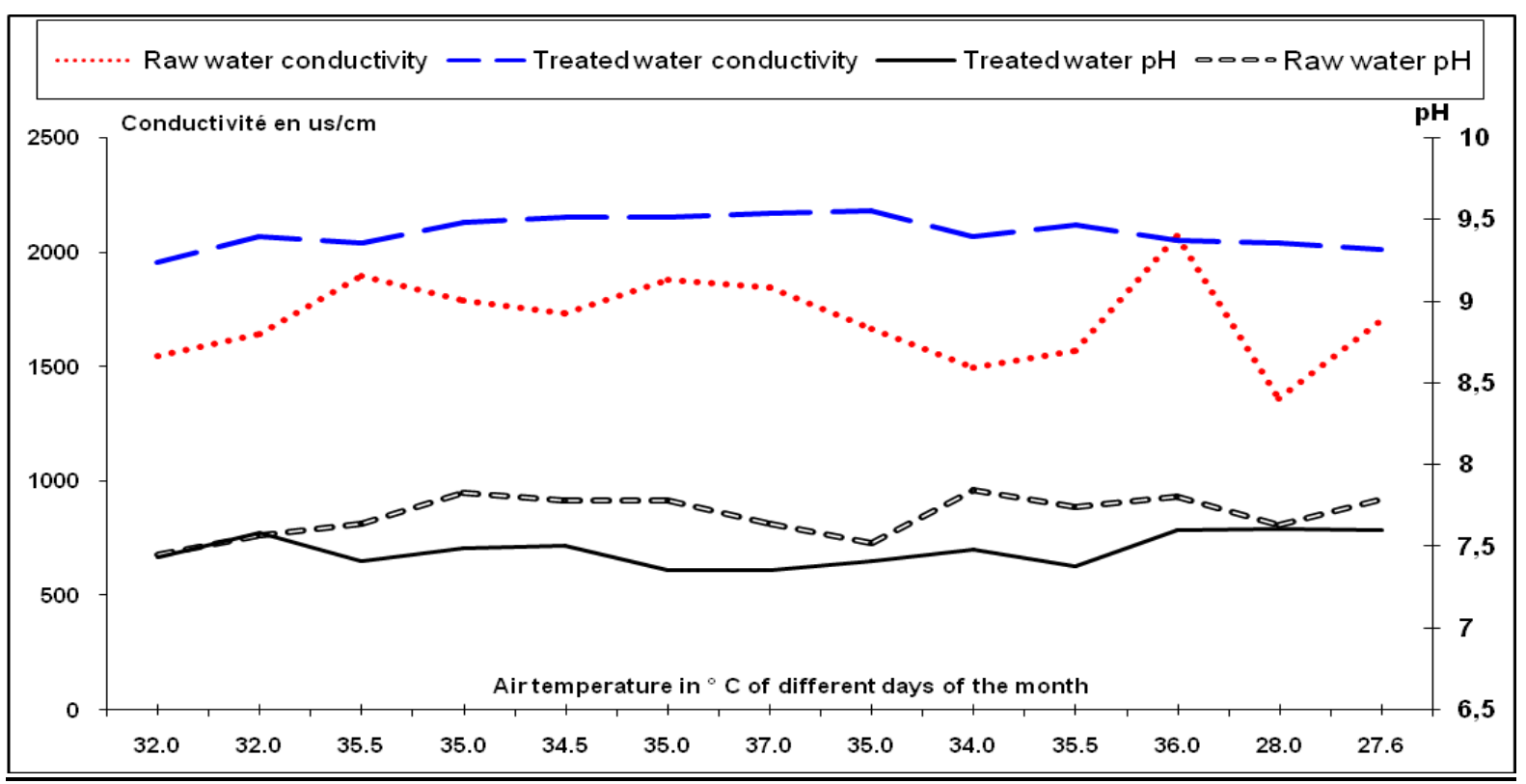

The conductivity values for the month of July 2010 vary between 1361 and $2070 \mu \mathrm{S} / \mathrm{cm}$ for raw water, between 1955 and $2180 \mu \mathrm{S} / \mathrm{cm}$ for treated water. For $\mathrm{pH}$, it varies between 7,45 and 7,84 for raw water and between 7,35 and 7,61 for those treated.

Table 1: Physico-chemical parameters in 2008

\begin{tabular}{|c|c|c|c|c|c|c|}
\cline { 2 - 7 } \multicolumn{1}{c|}{} & \multicolumn{3}{c|}{ February } & \multicolumn{3}{c|}{ May } \\
\hline Parameters & WWTP & $\begin{array}{c}\text { Outpout } \\
\text { WWTP }\end{array}$ & $\begin{array}{c}\text { efficiency } \\
(\%)\end{array}$ & $\begin{array}{c}\text { Entry } \\
\text { WWTP }\end{array}$ & $\begin{array}{c}\text { Outpout } \\
\text { WWTP }\end{array}$ & $\begin{array}{c}\text { efficiency } \\
(\%)\end{array}$ \\
\hline BOD $_{5}\left(\mathrm{mg} \mathrm{O}_{2} / \mathrm{L}\right)$ & 480 & 320 & 33,34 & 380 & 150 & 60,50 \\
\hline $\mathrm{COD}\left(\mathrm{mg} \mathrm{O} \mathrm{O}_{2 /} \mathrm{L}\right)$ & 1100 & 680 & 38,19 & 840 & 410 & 51,2 \\
\hline $\mathrm{SS}(\mathrm{mg} / \mathrm{L})$ & 290 & 95 & 67,25 & 430 & 95 & 77,91 \\
\hline
\end{tabular}

The biochemical oxygen demand $\left(\mathrm{BOD}_{5}\right)$, is one of the physico-chemical parameters estimation biodegradable organic carbon in water. In polluted areas, the carbon is used by bacteria as an energy source. This degradation can take place in the presence or absence of oxygen [8] During the two companions of 2008, we find that the values of $\mathrm{BOD}_{5}$ have to input a maximum value $480 \mathrm{mg} / \mathrm{L}$, and exit $320 \mathrm{mg} / \mathrm{L}$, with an efficiency of up to $60,5 \%$. The chemical oxygen demand (COD) is used to evaluate the concentration of dissolved inorganic or organic materials, or in suspension in water, through the amount of oxygen required for the total chemical oxidation. For our case, the COD of waste water at the inlet and outlet respectively has an average of $970 \mathrm{mg} / \mathrm{L}$ and $545 \mathrm{mg} / \mathrm{L}$ a yield of 51,2\% reduction which reached. The Suspended Solids (SS), are all mineral and organic particles in wastewater. Their effects on the physicochemical characteristics of the water are very harmful (change in turbidity, reducing light penetration thus photosynthesis). The analysis shows that wastewater from Errachidia city, have an average of $360 \mathrm{mg} / \mathrm{L}$ at study entry, and $95 \mathrm{mg} / \mathrm{L}$ at the outlet, with a good yield of $78 \%$. 
Table 2: Physico-chemical parameters in 2009

\begin{tabular}{|c|c|c|c|c|c|c|}
\cline { 2 - 7 } \multicolumn{1}{c|}{} & \multicolumn{3}{|c|}{ February } & \multicolumn{3}{c|}{ August } \\
\hline Parameters & Entry WWTP & $\begin{array}{c}\text { Outpout } \\
\text { WWTP }\end{array}$ & $\begin{array}{c}\text { efficiency } \\
(\%)\end{array}$ & Entry WWTP & $\begin{array}{c}\text { Outpout } \\
\text { WWTP }\end{array}$ & $\begin{array}{c}\text { efficiency } \\
(\%)\end{array}$ \\
\hline BOD $_{5}\left(\mathrm{mg} \mathrm{O}_{2} / \mathrm{L}\right)$ & 350 & 320 & 8,57 & 200 & 120 & 40 \\
\hline $\mathrm{COD}\left(\mathrm{mg} \mathrm{O} \mathrm{O}_{2 /} \mathrm{L}\right)$ & 740 & 540 & 27,02 & 640 & 400 & 37,5 \\
\hline $\mathrm{SS}(\mathrm{mg} / \mathrm{L})$ & 240 & 84 & 65 & 240 & 88 & 63,33 \\
\hline
\end{tabular}

From the table above, we find that the returns in terms of reduction of $\mathrm{BOD}_{5}$ and $\mathrm{COD}$ are low during February companion contribution by that August. For SS, they presented a concentration of $240 \mathrm{mg} / \mathrm{L}$ at the entrance, and an average of $86 \mathrm{mg} / \mathrm{L}$ at the output, with a maximum yield of $63 \%$.

Table 3: Physico-chemical parameters in 2010

\begin{tabular}{|c|c|c|c|}
\cline { 2 - 4 } \multicolumn{1}{c|}{} & \multicolumn{3}{c|}{ June } \\
\hline Parameters & Entry WWTP & Outpout WWTP & efficiency $(\%)$ \\
\hline BOD $_{5}\left(\mathrm{mgO}_{2} / \mathrm{L}\right)$ & 170 & 75 & 56 \\
\hline $\mathrm{COD}^{1}\left(\mathrm{mgO}_{2} / \mathrm{L}\right)$ & 480 & 250 & 48 \\
\hline $\mathrm{SS}(\mathrm{mg} / \mathrm{L})$ & 180 & 53 & 71 \\
\hline
\end{tabular}

For the month of June 2010, it was observed that the concentrations in terms of $\mathrm{BOD}_{5}, \mathrm{COD}, \mathrm{SS}$ at the outlet are reduced relative to the input, which tells us a good return abatement and especially for my reaching $71 \%$.

\section{DISCUSSION OF RESULTS}

\section{Quantitative evaluation}

It is observed that the inflow to the sewage treatment plant, remain below the rated capacity $\left(6000 \mathrm{~m}^{3} / \mathrm{d}\right)$ design of the station by 2010. But we note that there is an increase in rates from 2006 to 2010, this increase is related to the spleen laundry charges of connection to the sewerage system.

\section{Qualitative evaluation \\ Parameters on site}

In all the figures, we see that the values of $\mathrm{pH}$ and conductivity of raw water fluctuate with temperature while those treated water change very little. This is explained by the fact that raw water is responsible for organic and inorganic materials capable of releasing molecules loaded (this phenomenon is much more intense high mid-day temperature). While treated water is weakly concentrated pollutants and thus the amount of products that can solubilize or generate ions is low. The $\mathrm{pH}$ of the raw water is weakly basic, while that of treated water gets closer to neutrality. On the other hand, the range of $\mathrm{pH}$ of treated water within the limits of waste discharges values [9]. For conductivity, it is noted that the treated water is higher than that of raw water due to evaporation and degradation of the organic material in inorganic material. We also note that during the summer there is the influence of elevated temperatures on the treatment efficiency. Indeed, in winter the measured parameters for raw and treated water are neighbors. While during the summer the difference is remarkable.

\section{Physico-chemical parameters \\ WWTP Entry:}

Most mergers and pollution parameters $\left(\mathrm{COD}, \mathrm{BOD}_{5}, \mathrm{SS}\right)$ for years 2008, 2009 and 2010 are within the ranges typical Moroccan urban wastewater [7], except:

- $\mathrm{BOD}_{5}$ of February 2008 (exceeding 20\%);

- COD of February 2008 (exceeding 37\%);

- COD of May 2008 (exceeding 5\%) ;

- COD of November 2009 (exceeding 6\%). 


\section{WWTP Outpout}

physico-chemical quality

The effluent of the WWTP (output anaerobic lagoons) has values comply with the limit values [10], except:

- $\mathrm{BOD}_{5}$ and COD of February 2008 (respective exceeded 7\%, 13\%);

- $\mathrm{BOD}_{5}$ February 2009 and COD August 2009 (exceeding the respective 7\%, 13\%).

On the other hand, we observe that the yields are high in the months when the temperature is high.

\section{microbiological quality}

The quality of the effluent of the WWTP is consistent with a reuse of treated wastewater for cultivation of the Class B and C, but not consistent for crop irrigation in category A (crop may be consumed raw and land for public access) [11].

\section{CONCLUSION}

After monitoring the Errachidia wastewater treatment plant, we can deduce that:

1. for the inflow to the station, it has seen an increase in the years 2009 and 2010 due to the increased rate of connection to the sewerage;

2. for the treatment efficiency of the station it temperature dependent, however, the yield reached in June 2008 the respective percentages of $78 \%, 51 \%$ and $60 \%$ in terms of SS, COD and $\mathrm{BOD}_{5}$.

Moreover, this performance is limited because the treatment is limited in anaerobic lagoons. why pout and meet new emission standards [11], we recommend two solutions:

1. Improving the technique used in making the facultative lagoons and maturation ;

2. The transfer of natural lagoons in aerated lagoons, anaerobic lagoons feeding by existing aerators.

\section{BIBLIOGRAPHICAL REFERENCES}

[1] Degremont, 1989, Volume 2 Treatment Handbook of Water, 357-360.

[2] B. El hamouri et al, avril ,2000, The performance of a high-rate algal pond in the Moroccan climate, Rev. Water Science and Technology, volume 31,67-74.

[3] J. Paing, J. Psambuco, R.costa, A. Rambaud, B. Picot, 2003, Mass balance of carbone in anaerobic ponds applied under a Mediterranean climat, Rev.Sci.Eau, 357-368.

[4] Center of expertise in environmental analysis of Quebec Determination of chemical oxygen demand in effluents: methods of reflux in a closed system followed by a colorimetric assay with potassium dichromate-MA.315-DCO1.0 of 2/3/1999.

[5] Standard Moroccan, Determination of suspended solids, NM 03.7.052 (1996).

[6] Belles-Isles J.C. et al. 2004. National Institute of Public Health of Quebec. Summaries sheets on Drinking Water and Human Health

[7] National Office of Drinking Water, Schematic Directorate National Sanitation Liquid (SDNAL), May 1998, project MOR/92/020 Mission II.6, treatment, DEA, DGCL, Minister of the Interior

[8] Samudro G. et al. 2010 Journal of BOD, COD and BOD / COD: a triangular area for toxic, biodegradable and stable levels. Intenational Journal: Academy and Research. Vol. 2. \# 4. July 2010

[9] Limit values of direct and indirect discharges of Morocco, Ministry of Environment of Morocco. "Moroccan Standards, Official Bulletin of Morocco", No. 5062 of 30 Ramadan 1423. Rabat 2002;

[10] Official Gazette No. 5448 of Thursday, 17 August 2006 laying down specific limit values of wastewaters.

[11] Official Gazette No. 5062 dated 30 Ramadan 1423 (December 5, 2002) laying down standards of water quality for irrigation. 